\title{
Dekada kryzysu w Libii jako wyzwanie dla Unii Europejskiej (2011-2021)
}

Z początkiem drugiej dekady XXI stulecia przez Bliski Wschód i północną Afrykę przetoczyła się fala protestów społecznych, które wkrótce okrzyknięto mianem Arabskiej Wiosny. W niektórych państwach, jak np. Tunezja, jej przebieg był stosunkowo łagodny, prowadząc do niemal bezkrwawych zmian na szczytach władzy. W niektórych jednak pochłonęła wiele ofiar - szczególnie brutalnie dotknęła Syrię, która pogrążyła się w przewlekłej wojnie domowej. Innym przykładem nieudanej próby demokratyzacji okazał się Egipt, w którym po obaleniu Hosniego Mubaraka i krótkiej prezydenturze Muhammada Mursiego, ostatecznie na czele państwa stanął Abd al-Fattah as-Sisi. Jednym z najbardziej niespokojnych frontów Arabskiej Wiosny okazała się Libia. Celem artykułu jest przybliżenie aktywności Unii Europejskiej wobec trwającego już dekadę (2011-2021) kryzysu w Libii, zapoczątkowanego wybuchem wojny domowej i obaleniem Muammara Kaddafiego. Omówione zostaną przede wszystkim operacje prowadzone przez UE w reakcji na wydarzenia w Libii, której niestabilność stała się źródłem poważnych problemów dla Europy, związanych głównie z presją migracyjną i zagrożeniem terroryzmem. Oczywiście działania UE wobec Libii nie toczyły się w międzynarodowej próżni, także Organizacja Narodów Zjednoczonych była żywo zainteresowana stabilizacją sytuacji w tym północnoafrykańskim państwie. $Z$ tego względu, oprócz stosownych decyzji podjętych przez UE (zwłaszcza Radę Europejską i Radę) omówione zostały najważniejsze rezolucje Rady Bezpieczeństwa ONZ. Jest to o tyle istotne, że były one z kolei podstawą prawną decyzji podejmowanych przez instytucje UE. Oprócz zasygnalizowanych dokumentów UE i RB ONZ istotną rolę w przygotowaniu artykułu odegrały opracowania, w dużej mierze niemieckojęzyczne, co wynikało przede wszystkim z istotnej roli, jaką RFN odegrała w stabilizacji sytuacji w Libii na przełomie drugiej i trzeciej dekad XXI wieku, gdy Berlin gościł dwie konferencje międzynarodowe poświęcone tej sprawie (na temat aktywności Niemiec w Afryce zob. Kruk, 2020). Śledząc przebieg wydarzeń można sformułować hipotezę, że aktywność Unii Europejskiej wobec Libii rozpatrywana w szerszym kontekście związanym z aktywnością innych aktorów zainteresowanych wzmacnianiem wpływów w tym państwie, przyczyniła się do umiarkowanej stabilizacji sytuacji w Libii, której trwałość jest kwestią otwartą. W przygotowaniu artykułu posłużono się przede wszystkim metodą monograficzną i metodą badania dokumentów.

Protesty, jakie wybuchły w lutym 2011 r. przeciwko sprawującemu władzę od 1969 r. Muammarowi Kaddafiemu, przekształciły się wkrótce w regularne powstanie. Głównym gniazdem oporu stało się nadmorskie Bengazi. Otwarte groźby Kaddafiego wobec ludności zbuntowanego miasta dostarczyły doskonałego uzasadnienia dla 
szybkich działań Rady Bezpieczeństwa ONZ, która ogłosiła dwie rezolucje dotyczące Libii - 26 lutego 2011 r. (rezolucja 1970) a następnie 17 marca 2011 r. (rezolucja 1973). W pierwszej potępiano łamanie praw człowieka i stosowanie przemocy wobec ludności cywilnej w Libii. Powoływano się w niej także na stanowisko regionalnych organizacji - Ligi Państw Arabskich i Organizacji Konferencji Islamskiej. Domagano się m.in. zaprzestania przemocy, dopuszczenia na obszar Libii obserwatorów międzynarodowych i pomocy humanitarnej oraz zapewnienia bezpieczeństwa obywatelom innych państw. Na kilkanaście osób związanych z władzami, włącznie z Kaddafim, nałożono sankcje wizowe, części spośród nich zamrożono zasoby finansowe. Ponadto nałożone zostało embargo na dostawy broni do Libii. Należy podkreślić, że za rezolucją 1970 zagłosowali wszyscy członkowie Rady Bezpieczeństwa (Resolution 1970).

Druga z wymienionych, tj. rezolucja 1973, otworzyła z kolei prawną furtkę dla zbrojnej interwencji przeciwko Kaddafiemu, odwołując się do zasady „odpowiedzialności za ochronę" (Responsibility to Protect). W diagnozie sytuacji powtarzała zarzuty z rezolucji 1970. Przywołała rozdział VII Karty Narodów Zjednoczonych jako podstawę dla ewentualnych działań przeciwko siłom Kaddafiego. W dokumencie znalazła się zapowiedź zastosowania „wszelkich możliwych środków” w celu obrony ludności cywilnej „przed atakiem ze strony Libijskiej Arabskiej Dżamahirii”, tj. sił zbrojnych Kaddafiego. Wprowadzono strefę zakazu lotów nad Libią. Pojawiło się skierowane do członków ONZ zalecenie nieudostępniania swych przestrzeni powietrznych libijskim statkom powietrznym. Postanowiono ponadto zamrozić libijskie zasoby finansowe (Resolution 1973). Znamienny był fakt, że - w przeciwieństwie do rezolucji 1970 - w głosowaniu nad tym dokumentem wstrzymało się pięć państw: Chiny, Rosja, Indie, Brazylia i Niemcy. Warto na marginesie odnotować, iż taka postawa Berlina spotkała się z krytyką ze strony państw Zachodu, popierających interwencję w Libii (krytycznie na temat przyczyn stanowiska Niemiec zob. Schoch, 2014).

Jak wspomniano, z perspektywy państw popierających interwencję w Libii, działanie to mieściło się w ramach Responsibility to Protect. Władze w Trypolisie stwarzały zagrożenie dla ludności własnego państwa oraz dla społeczności międzynarodowej. W rezolucji nie zapowiedziano dosłownie użycia środków militarnych, jednak sformułowanie o możliwości zastosowania wszelkich możliwych środków w celu zapobieżenia łamaniu praw człowieka w praktyce tak zostało odczytane. Już 19 marca 2011 r. w ramach operacji Odyssey Dawn (z udziałem kilku państw NATO, Kataru i Zjednoczonych Emiratów Arabskich) rozpoczęły się ataki pociskami manewrującymi tomahawk na cele libijskie. Kilkanaście dni później, 31 marca 2011 r. NATO przejęło pełną odpowiedzialność za działania przeciwko siłom Kaddafiego w ramach operacji Unified Protector. Siły opozycyjne zostały dozbrojone i wsparte operacjami jednostek specjalnych państw uczestniczących. Ataki lotnicze siały zniszczenie wśród wojsk rządowych. Autoryzacja ze strony Rady Bezpieczeństwa ONZ była niewątpliwie czynnikiem sprzyjającym działaniom koalicji. Rezolucja 1973 nie wskazywała wprawdzie obalenia Kaddafiego jako celu działań militarnych, jednak wkrótce stało się oczywiste, że Amerykanie, Brytyjczycy i Francuzi wyraźnie sprzyjali takiemu scenariuszowi (Sponeck, s. 62).

Wydarzenia w Libii nie pozostały bez reakcji społeczności międzynarodowej. 16 września 2011 r. w Radzie Bezpieczeństwa zaaprobowana została rezolucja nr 2009, 
na mocy której powołano Misję Wparcia Narodów Zjednoczonych dla Libii (United Nations Support Mission for Libya, UNSMIL) (Resolution 2009). Jej mandat, wielokrotnie w kolejnych rezolucjach rozszerzany i precyzowany, obejmował m.in.: działania na rzecz demokratyzacji państwa (organizacja wyborów, uchwalenie konstytucji), rozwój społeczeństwa obywatelskiego, w tym udziału mniejszości narodowych oraz kobiet w życiu publicznym, wspieranie odbudowy instytucji państwowych, zwłaszcza w sektorze bezpieczeństwa, demobilizację osób biorących udział w walkach i włączanie ich do życia społecznego itd.

Śmierć Muammara Kadafiego, który zginął z rąk powstańców w październiku 2011 r., nie przyniosła oczekiwanej stabilności, wprost przeciwnie - Libia stoczyła się w otchłań wojny domowej z udziałem ogromnej liczby podmiotów, kierujących się własnymi interesami i chwiejnymi sojuszami. Próbę opanowania chaosu stanowiły wybory do 200-osobowego Powszechnego Kongresu Narodowego (ang. General National Congress) 7 lipca 2012 r. 120 posłów wybierano w oparciu o ordynację większościową, pozostałych $80 \mathrm{z}$ list partyjnych według ordynacji proporcjonalnej. Spośród nich najwięcej mandatów, tj. 39, uzyskał tzw. Sojusz Sił Narodowych (ang. National Forces Alliance), drugie z liczbą 17 mandatów formacja pod nazwą Prawo i Odbudowa (ang. Justice and Construction) zbliżona do Bractwa Muzułmańskiego. Pozostałe miejsca uzyskali przedstawiciele aż 18 ugrupowań (szczegółowe wyniki wyborów zob. raport the Carter Center: General National Congress, 2012, s. 90-100). Niestabilność sceny politycznej, charakteryzująca się rywalizacją formacji świeckich i religijnych, stała się przyczyną kolejnych, przyspieszonych wyborów 25 czerwca 2014 r. do parlamentu (Izby Reprezentantów). Od początku jednak zarysował się konflikt pomiędzy nowo wyłonioną Izbą Reprezentantów a dotychczasowym Powszechnym Kongresem Narodowym, który kontynuował swą działalność w Trypolisie. Izba Reprezentantów natomiast ulokowała swą siedzibę w Tobruku. W taki oto sposób w połowie 2014 r. rozpoczął się okres dwuwładzy - w obu wspomnianych miastach funkcjonowały odrębne parlamenty, rządy, które dysponowały własnymi formacjami zbrojnymi. Względną stabilizację przyniosło podpisane 17 grudnia 2015 r. porozumienie, które doprowadziło do utworzenia Rządu Porozumienia Narodowego (ang. Government of National Accord) (Libyan Political, 2015). Na jego czele stanął Fajiz as-Saradż. Początkowo został ulokowany w Tunisie, a od lipca 2016 r. w Trypolisie, jednak jego prawomocność była kwestionowana. Na największą siłę opozycyjną wyrosła tzw. Libijska Armia Narodowa pod przywództwem gen. Halify Haftara, kontrolująca wschodnią Libię. Sytuację dodatkowo komplikowała aktywność licznych pomniejszych ugrupowań zbrojnych, opartych na więzach plemiennych bądź religijnych, w tym Państwa Islamskiego (Szczepankiewicz-Rudzka, 2018).

Jedną z najpilniejszych potrzeb związanych z kryzysem libijskim stało się zabezpieczenie jej granic, w tym południowej, przez którą zarówno przemycani byli potencjalni azylanci kierujący się do Europy, jak i uzbrojeni bojownicy. Z perspektywy Unii Europejskiej, której groziła presja migracyjna z północnej Afryki, była to kwestia o strategicznym znaczeniu. Decyzja w tej sprawie zapadła na Radzie UE dnia 22 maja 2013 r. - postanowiono wówczas powołać do życia misję wspierającą ochronę granic Libii, na prośbę legalnych władz tego państwa. Jako cele misji wskazano w krótszej perspektywie wsparcie Libii w zakresie umacniania bezpieczeństwa granic lądowych, 
morskich i powietrznych, zaś w dłuższej - pomoc w przygotowaniu strategii zintegrowanego zarządzania granicami. Ponadto miała za zadanie wesprzeć przygotowanie całościowej reformy cywilnego sektora bezpieczeństwa w perspektywie ewentualnej misji w obszarze zarządzania kryzysowego. Wśród zadań misji wymieniono: szkolenia i mentoring w celu wzmacniania służb granicznych, doradztwo przy opracowaniu strategii zarządzania granicami oraz pomoc w poprawie instytucjonalnych zdolności operacyjnych (Decyzja 2013/233/WPZiB). Została ona uzupełniona decyzją z 15 lutego $2016 \mathrm{r}$. w kontekście przygotowań do ewentualnego powołania misji w obszarze zarządzania kryzysowego w dziedzinie budowania zdolności cywilnych oraz wsparcia reformy sektora bezpieczeństwa (Decyzja Rady /WPZiB/ 2016/207). Pierwszym szefem misji EUBAM Libya został fiński dyplomata Antti Juhani Hartikainen, który 1 września 2016 r. zastąpiony został Włochem Vincenzo Tagliaferrim, zaś 1 lutego 2021 r. funkcję tę przejęła jego rodaczka Natalina Cea (EUBAM Libya: nowy szef, 2021). Misja była kilkukrotnie przedłużana - ostatni raz 18 czerwca 2021 r., do 30 czerwca 2023 r. (EUBAM Libya: Rada przedtuża, 2021).

Jak wcześniej sygnalizowano, śmierć Kaddafiego nie zakończyła wojny domowej w Libii, która staczała się w otchłań przemocy. Rozkład państwa sprzyjał aktywności band zbrojnych, które opanowując wybrzeże czerpały korzyści z przemytu ropy naftowej oraz ludzi, szukających lepszych szans na życie w Europie. Nic dziwnego zatem, że zaczął następować wzrost presji migracyjnej z Libii w kierunku Włoch przez Morze Śródziemne. Próbą opanowania tego trendu stała się zainicjowana przez Włochy operacja Mare Nostrum w październiku 2013 r. Koncentrowała się ona na przejmowaniu obiektów nawodnych z imigrantami i przewożeniu ich do portów włoskich (ok. 130 tys. imigrantów w ciągu roku). W 2014 r. została ona z inicjatywy Włoch przekształcona w unijną operację Tryton (Mickiewicz, 2017, s. 127). Ta z kolei w 2018 r. została zastąpiona operacją Temida pod kierownictwem Frontexu, skoncentrowaną na działaniach poszukiwawczych i ratowniczych oraz antyterrorystycznych. Frontex prowadził ponadto misje zabezpieczające szlak morski pomiędzy Grecją a Turcją - Posejdon (od 2016 r.), oraz pomiędzy Marokiem a Hiszpanią - Indalo.

19 marca 2014 r. uchwalona została rezolucja Rady Bezpieczeństwa nr 2146. Jej głównym celem było zapobieganie przemytowi ropy naftowej z Libii. Przewidywała ona współpracę z władzami Libii w celu zahamowania tego procederu, dopuszczała przeprowadzanie inspekcji statków na Morzu Śródziemnym. W kilkunastu punktach precyzowała zasady przeprowadzania takich inspekcji (Resolution 2146 (2014)). Stała się ona jednym z podstawowych dokumentów, o które opierały się późniejsze decyzje Unii Europejskiej.

W dniach 11-12 listopada 2015 r. odbył się w Valetcie szczyt państw europejskich i afrykańskich w sprawie migracji. W rezultacie przyjęto wspólną deklarację, plan działania oraz postanowiono utworzyć nadzwyczajny fundusz powierniczy na rzecz stabilności i likwidowania przyczyn migracji. Zadeklarowano wspólne dążenie do zarządzania przepływami migracyjnymi (Valetta Summit, 2015), plan działania zawierał obszerny katalog konkretnych zamierzeń (Valetta Summit, 11-12 November 2015. Action Plan).

3 lutego 2017 r. ogłoszona została deklaracja Rady Europejskiej dotycząca problemów migracji przez Morze Śródziemne. Z zadowoleniem skonstatowano w niej 
spadek migracji w 2016 r. w porównaniu do roku poprzedniego, w którym nastąpił szczyt naporu migracyjnego. Wskazano w niej kilka priorytetowych działań: wsparcie libijskiej straży przybrzeżnej; rozbijanie siatek przemytniczych, wspieranie libijskich społeczności lokalnych na obszarach przybrzeżnych w celu poprawy ich sytuacji ekonomiczno-społecznej; poprawa zdolności do przyjmowania migrantów w Libii; współpraca z sąsiadami Libii na rzecz poprawy zarządzania ich granicami; obserwacja alternatywnych szlaków przemytniczych; wspieranie Włoch w ich bilateralnej współpracy z rządem Libii i inne (Maltańska deklaracja, 2017).

Potwierdzeniem wysiłków na rzecz zwalczania nielegalnej migracji była wspólna deklaracja Unii Europejskiej, Unii Afrykańskiej i Organizacji Narodów Zjednoczonych z 29 listopada 2017 r. w Abidżanie. W dokumencie zapowiedziano utworzenie wspólnej grupy zadaniowej do spraw migracji, która miała zmierzyć się z wyzwaniami migracyjnymi, w szczególności presją migracyjną z Libii (Joint press release of the United Nations, 2017).

Uwarunkowania geograficzne przesądzały o tym, że Unia Europejska była szczególnie zainteresowana stabilizacją sytuacji w Libii. Odpowiedzią na to wyzwanie był szereg działań w reakcji na zagrożenia związane z aktywnością przestępczą w Libii i na Morzu Śródziemnym - przede wszystkim przemytem ludzi i broni. Głównym narzędziem w zwalczaniu tych zjawisk miała stać się operacja EUNAVFOR MED Sophia na tym akwenie. Działania zmierzające do wdrożenia operacji stały się możliwe po nadzwyczajnym szczycie Rady Europejskiej 23 kwietnia 2015 r. W oświadczeniu końcowym spotkania postanowiono zwiększyć obecność UE na Morzu Śródziemnym, wzmacniając finansowo operacje Tryton i Posejdon. Ponadto podkreślono konieczność przeciwdziałania przemytowi ludzi, przede wszystkim poprzez zwalczanie sieci przemytniczych, stawianie sprawców przed wymiarem sprawiedliwości, zajmowanie ich aktywów i likwidowanie statków służących do przemytu. Zaakcentowano także konieczność udaremniania nielegalnej migracji, poprzez wsparcie dla Mali, Nigru, Sudanu i Egiptu na rzecz poprawy monitorowania lądowych szlaków migracyjnych, wzmocnienie kooperacji z Turcją i przygotowanie regionalnych programów rozwojowych dla Rogu Afryki i państw północnej części kontynentu. W końcowej części konkluzji podkreślono potrzebę wzmocnienia wewnątrzunijnej solidarności, m.in. poprzez realizację europejskiego systemu azylowego czy nadzwyczajne wsparcie dla państw znajdujących się na pierwszej linii zetknięcia z imigracją, rozmieszczenie w nich zespołów Europejskiego Urzędu Wsparcia w Dziedzinie Azylu dla pomocy w rozpatrywaniu wniosków azylowych, czy też rozważenie możliwości dobrowolnych relokacji imigrantów (Nadzwyczajne posiedzenie Rady Europejskiej).

Podstawą prawną operacji Sophia stała się decyzja Rady UE ds. Zagranicznych z 18 maja 2015 r. Dokument uzasadniał powołanie operacji trudną sytuacją na Morzu Śródziemnym i akcentował konieczność walki z przemytem ludzi, niosącym liczne ofiary śmiertelne. Odwołano się w niej do kilku kluczowych aktów prawa międzynarodowego, przede wszystkim: Konwencji o prawie morza, Konwencji przeciwko międzynarodowej przestępczości zorganizowanej, Międzynarodowej konwencji o bezpieczeństwie życia na morzu, Międzynarodowej konwencji o poszukiwaniu i ratownictwie morskim, Konwencji o ochronie środowiska morskiego i regionu przybrzeżnego Morza Śródziemnego oraz Konwencji genewskiej dotyczącej statusu 
uchodźców. Jako mandat misji, podzielonej na trzy fazy, określono wykrywanie i monitorowanie sieci migracyjnych na morzu. Patrole morskie zyskiwały uprawnienie do wchodzenia na pokład podejrzanych statków, dokonywania przeszukań, zajmowania i zawracania, a także unieszkodliwiania statków używanych do przemytu ludzi. Decyzja Rady upoważniała misję także do gromadzenia danych osobowych w trakcie prowadzonych działań. Dowództwo ulokowano w Rzymie, zaś jej kierowanie powierzono włoskiemu admirałowi Enrico Credendino (Decyzja Rady (WPZiB) 2015/778). Operacja formalnie rozpoczęła się 22 czerwca 2015 r. w oparciu o decyzję Rady UE ds. Zagranicznych (Decyzja Rady (WPZiB) 205/972). Dnia 7 października 2015 r. operacja weszła w drugą fazę, zgodnie z decyzją Komitetu Politycznego i Bezpieczeństwa z 28 września 2015 r. (Decyzja Komitetu Politycznego i Bezpieczeństwa (WPZiB) 2015/1772), w której przewidywano możliwość wkraczania na pokłady podejrzanych statków, ich przeszukiwania, zawracanie czy zajmowania. UE w toku realizacji misji jednocześnie starała się o przychylność i współpracę libijskiego Rządu Jedności Narodowej, admirał Credendino miał obiecywać wsparcie w budowie libijskiej marynarki i straży przybrzeżnej (Estrada- Canamares, 2016, s. 188).

Sytuacja na Morzu Śródziemnym stała się także przedmiotem rezolucji Rady Bezpieczeństwa ONZ z 9 października 2015 r. Podobnie jak w decyzji Rady UE, potępiono w niej przemyt ludzi oraz wezwano do wsparcia Libii w celu zapobiegania temu procederowi (Resolution 2240). Potwierdzeniem ścisłego współdziałania ONZ i UE była decyzja Komitetu Politycznego i Bezpieczeństwa z 20 stycznia 2016 r. w sprawie wdrożenia rezolucji RB 2240 (Decyzja Komitetu Politycznego i Bezpieczeństwa (WPZiB) 2016/118). 20 czerwca 2016 r. na mocy decyzji Rady ds. Zagranicznych nastąpiło rozszerzenie zadań opisywanej misji o szkolenie libijskiej marynarki i straży przybrzeżnej oraz udział we wdrażaniu nałożonego przez Radę Bezpieczeństwa ONZ (na mocy kilku rezolucji, poczynając od rezolucji 1970 z 2011 r.) embarga na broń na morzu otwartym. W dokumencie z zadowoleniem odnotowano gotowość libijskiego Rządu Jedności Narodowej do współpracy z UE (Decyzja Rady (WPZiB) 2016/993). W operacji udział wzięła zdecydowana większość państw UE, oddając do jej dyspozycji statki, śmigłowce i inny sprzęt. Do 2017 r. w ramach misji zneutralizowano 491 łodzi, aresztowano i przekazano władzom Włoch 117 osób podejrzanych o przemyt ludzi, uratowano ponad 40 tys. migrantów. Jednocześnie Włochy, najbardziej zainteresowane powstrzymaniem migracji, wdrożyły programy wzmacniania libijskiej marynarki i straży przybrzeżnej (Tardy, 2017, s. 3-4). W kolejnych latach następowały dalsze konkluzje i decyzje Rady Europejskiej i Rady w sprawie Libii, zmierzające do ograniczenia migracji na szlaku śródziemnomorskim, akcentujące także aktywność innych podmiotów unijnych - w tym Europolu i Frontexu (Decyzja Rady (WPZiB) 2017/1385). Misja była regularnie przedłużana, by ostatecznie wygasnąc 31 marca 2020 r. (Decyzja Rady (WPZiB) 2020/471). W lutym 2020 r. podjęto decyzję o nieprzedłużaniu jej mandatu. Do głównych jej oponentów należały Austria i Włochy. Wiedeń argumentował, że operacja praktycznie przekształciła się w misję ratunkową, bowiem obecność unijnych okrętów na Morzu Śródziemnym, ratujących afrykańskich rozbitków próbujących dostać się do Europy, stanowiła zachętę dla potencjalnych migrantów (Kurz lehnt, 2020). Podobnego zdania był Rzym, który dodatkowo podkreślał, że obserwacje i patrole na morzu należałoby rozszerzyć o nadzór dróg lądowych 
i powietrznych. Powyższe zastrzeżenia dostrzegane były także w innych państwach (Widerstand gegen). Należy zresztą zauważyć, że z powodu ostrych protestów Włoch, a tym samym napięć panujących w UE na tle podziału obciążeń migracyjnych dla poszczególnych państw, już z końcem marca 2019 r. wstrzymano działania okrętów misji, ograniczając się do obserwacji powietrznych i szkolenia libijskiej marynarki i straży przybrzeżnej (Kirtzman, 2020).

W zbliżonym czasie także na forum ONZ podjęto decyzje w sprawie Libii. W dniach 11 i 12 lutego 2020 r. Rada Bezpieczeństwa ONZ uchwaliła dwie rezolucje dotyczące tego niestabilnego państwa. Pierwsza z nich - nr 2509 - odwoływała się do rezolucji 2146 z 2014 r. i przedłużała nałożony wówczas zakaz nielegalnego wywozu ropy naftowej z Libii. Postanowiono w niej również kontynuować prace grupy ekspertów powołanej rezolucją 1973 z 2011 r. Dokument nawoływał ponownie do przestrzegania nałożonego na Libię embarga na broń (Resolution 2509). Z kolei w rezolucji 2510 zaaprobowane zostały efekty niedawnej konferencji berlińskiej w sprawie Libii. Wzywała ona wszystkie państwa do powstrzymania się od ingerowania w konflikt i tym samym podsycania niestabilności (Resolution 2510).

Nieco wcześniej, bo w 2019 r. w Libii ponownie rozgorzała wojna domowa, gdy wojska generała Chalify Haftara zaatakowały zachodnią część kraju, kontrolowaną przez rząd premiera Fajiza as-Sarradża. Szybkie zdobycze terytorialne wojsk Haftara, cieszącego się wsparciem Zjednoczonych Emiratów Arabskich, Egiptu, Rosji czy Francji, doprowadziły do bezpośredniego zagrożenia Trypolisu w kwietniu tego roku. To z kolei skłoniło innych aktorów zewnętrznych do zaangażowania się po stronie legalnych władz Libii. Uzyskały one poparcie m.in. Włoch, Algierii, Kataru, a nade wszystko Turcji, która wsparła go przede wszystkim w postaci sprzętu wojskowego. Z kolei po stronie Haftara walczyli rosyjscy najemnicy z tzw. grupy Wagnera, od których Moskwa oficjalnie się odcinała, mimo że de facto uchodzili za narzędzie władz rosyjskich. Losy konfliktu jednak uległy odwróceniu i zamiast spodziewanego łatwego zajęcia Trypolisu, w 2020 r. następował odwrót wojsk Haftara. W tych okolicznościach nie brakowało oskarżeń o łamanie embarga na broń dostarczaną do Libii przez zewnętrznych aktorów - zwłaszcza przez Zjednoczone Emiraty Arabskie (siłom Haftara) oraz Turcję (siłom rządowym). Obie strony mogły dzięki temu wzmocnić swoje zdolności militarne, zwłaszcza dzięki użyciu dronów bojowych (Harchaoui, 2020).

Wobec eskalacji działań zbrojnych, ale i rysującej się sytuacji patowej w konflikcie, prawdopodobnie w następstwie nacisków Rosji i Turcji doszło do zawieszenia broni 12 stycznia 2020 r., zaś następnego dnia w Moskwie odbyły się kilkugodzinne rozmowy z udziałem obu państw oraz as-Sarradża i Haftara, choć obaj antagoniści jednak bezpośrednio się nie spotkali (Berliner Gipfel soll, 2020). Następnie inicjatywę dyplomatyczną przejęły Niemcy. Na ich zaproszenie, dnia 19 stycznia 2020 r. odbyła się konferencja stron zaangażowanych w Libii, na której spotkali się przedstawiciele prowadzących tam zastępczą wojnę Rosji i Turcji, ponadto Niemiec, Francji, Wielkiej Brytanii, Włoch, Chin, Zjednoczonych Emiratów Arabskich, Republiki Konga, Egiptu i Algierii. Udział wzięli także delegaci ONZ, UE, Unii Afrykańskiej i Ligi Państw Arabskich. Zaproszeni zostali też dwaj główni antagoniści konfliktu libijskiego: premier as-Sarradż i gen. Haftar (Waffenruhe, 2020). Do najważniejszych postanowień 
obszernej, bo 55-punktowej deklaracji końcowej, należały zawieszenie walk, przestrzeganie embarga na broń i powrót do dialogu politycznego. Ponadto podkreślono wiodącą rolę ONZ, przy jednoczesnej odpowiedzialności samych Libijczyków za proces pokojowy. Przewidziano regularny dialog na różnych szczeblach, m.in. w ramach tzw. komitetu „5+5”, złożonego z oficerów obu skonfliktowanych stron (Berliner Libyen-Konferenz, 2020).

Wracając do aktywności UE w sprawie Libii wypada odnotować, że zakończenie misji Sophia miało ścisły związek z uruchomieniem nowej misji - EUNAVFOR MED Irini, w formule nieco odmienionej od Sophii. 17 lutego 2020 r. nastąpiło porozumienie Rady w sprawie uruchomienia operacji. O ile głównym zadaniem Sophii było zwalczanie przemytu ludzi, to celem Irini stało się w pierwszym rzędzie nadzorowanie przestrzegania ONZ-owskiego embarga na broń do Libii. Misja miała w realizacji tego zadania wykorzystać zasoby powietrzne, morskie i satelitarne. Została upoważniona do gromadzenia danych dotyczących nielegalnego handlu bronią i materiałami powiązanymi. Uzyskała możliwość dokonywania inspekcji statków płynących z Libii lub do tego państwa. Odwołano się do przytaczanej wcześniej rezolucji Rady Bezpieczeństwa nr 2292 z 2016 r. Broń i materiały z nią powiązane mogły być niszczone po przekierowaniu do ustalonego portu któregoś z państw członkowskich UE. Ponadto misja miała gromadzić wszelkie informacje dotyczące sprawców zabronionych czynów związanych z przemytem broni w celu przekazania ich odpowiednim organom wymiaru sprawiedliwości (Decyzja Rady (WPZiB) 2020/472, art. 2). Ponadto wskazano następujące zadania, określone w decyzji Rady jako drugorzędne: monitoring i gromadzenie informacji dotyczących nielegalnego wywozu ropy naftowej z Libii (stanowiącego złamanie m.in. rezolucji RB 2146 i 2509) oraz przekazywanie ich - w razie potrzeby - organom UE i władzom libijskim (Decyzja Rady (WPZiB) 2020/472, art. 3); wsparcie budowy i szkolenie libijskiej marynarki wojennej i straży przybrzeżnej w zakresie egzekwowania prawa na morzu, zwłaszcza zapobiegania przemytowi ludzi (przewidziano możliwość prowadzenia patroli nie tylko na morzu otwartym, ale także na terytorium Libii lub państw sąsiednich, na podstawie zaproszenia wydanego przez dane państwo) (Decyzja Rady (WPZiB) 2020/472, art. 4); wykrywanie i monitorowanie sieci przemytu ludzi i handlu ludźmi, w oparciu o rezolucję RB nr 2240 z 2015 r., poprzez zbieranie informacji oraz patrole przy użyciu zasobów powietrznych na pełnym morzu (Decyzja Rady (WPZiB) 2020/472, art. 5). Kierowanie operacją powierzono włoskiemu kontradmirałowi Fabio Agostiniemu, zaś dowództwo misji zostało ulokowane w Rzymie. Przewidziano również możliwość zaproszenia państw trzecich do udziału w operacji (Decyzja Rady (WPZiB) 2020/472, art. 11). W misji udział wzięły 24 państwa (stan na lipiec 2021 r.), okres jej trwania przewidziano na trzy lata, do 31 marca 2023 r., zatem ocena jej efektów będzie wymagała pewnej perspektywy czasowej.

Proces pokojowy dla Libii kontynuowany był w 2021 r. Ponownie na zaproszenie rządu niemieckiego do Berlina zjechały delegacje kilkunastu państw i organizacji międzynarodowych zainteresowanych normalizacją sytuacji w tym państwie, by 23 czerwca spotkać się i omówić dalsze kroki. Okoliczności wydawały się stosunkowo sprzyjające, gdyż w wyniku rozmów w formacie „5+5" prowadzonych w Genewie od 23 października 2020 r. trwało już zawieszenie broni pomiędzy stronami 
konfliktu (UN: Dauerhafter, 2020). Od marca 2021 r. funkcjonował Rząd Jedności Narodowej (Government of National Unity) pod kierownictwem Abdulhamida Dabaiby (można się także spotkać z pisownią: Dabeiba, Dbeiba, Dbeibeh) oraz Rada Prezydencka kierowana przez Muhammada al-Manfiego. Ciała te powołane zostały przez 75-osobowe Libijskie Forum Dialogu Politycznego - organ złożony z przedstawicieli różnych grup społecznych Libii, powołany w listopadzie 2020 r. pod auspicjami ONZ (a właściwie misji UNSMIL), początkowo działający w Tunisie. Rząd premiera Dabaiby określany był jako przejściowy, zaś jego głównym zadaniem miało być przygotowanie państwa do wyborów parlamentarnych i prezydenckich. Druga konferencja berlińska ogniskowała się właśnie wokół tego celu. Drugim istotnym problemem poruszonym na konferencji stała się sprawa obecności obcych wojsk w Libii - przede wszystkim Turcji i Rosji (wspomnianej grupy Wagnera, od której Moskwa oficjalnie się odcinała), czy też najemników z różnych państw, głównie Syrii, ale i Sudanu czy Czadu (Volk, 2020, s. 2). W konferencji udział wzięli przedstawiciele Libii, Niemiec, Francji, Włoch, Wielkiej Brytanii, Holandii, Szwajcarii, Rosji, Stanów Zjednoczonych, Chin, Egiptu, Algierii, Tunezji, Turcji, Republiki Konga, Demokratycznej Republiki Konga, Zjednoczonych Emiratów Arabskich, ONZ, UE, UA i LPA. Najważniejsze zapisy znalazły się w 58-punktowej deklaracji końcowej konferencji. Skonstatowano w niej, że sytuacja w Libii poprawiła się od czasu poprzedniej konferencji berlińskiej (pkt 3). Wybory parlamentarne i prezydenckie w Libii przewidziano na 24 grudnia 2021 r. (pkt 4-5). Podkreślono rolę tzw. kwartetu libijskiego (ONZ, UE, UA, LPA) oraz UNSMIL i libijskich instytucji. W deklaracji położono również nacisk na konieczność wycofania z Libii najemników i wszelkich zagranicznych bojowników (The Second, 2021).

Pozytywną generalnie ocenę postanowień drugiej konferencji berlińskiej zakłócają istotne wątpliwości, odnoszące się do ich interpretacji. I tak na przykład Turcja utrzymuje, że nie dotyczą jej postanowienia odnoszące się do wycofania obcych wojsk, jej żołnierze są bowiem obecni w Libii na zaproszenie Trypolisu. Rosja z kolei - jak wcześniej wspomniano - wielokrotnie odcinała się oficjalnie od grupy Wagnera, utrzymując że nie ma ona nic wspólnego z Kremlem. Z chwilą ogłoszenia deklaracji końcowej konferencji nie było również jasne, według jakich reguł mają odbyć się wybory (proporcjonalne czy większościowe). Te kwestie musiały być zatem przedmiotem dalszych porozumień.

Mieszane uczucia wiążą się z oceną efektów działań UE wobec Libii. Szczególnie dotyczy to misji Sophia, która - zamiast realizować cele leżące u jej podłoża - w praktyce musiała skoncentrować się na działaniach ratowniczych, czemu zresztą trudno się dziwić w obliczu kryzysu humanitarnego w północnej Afryce i na Morzu Śródziemnym. Wnioski wyciągnięte z Sophii doprowadziły do powołania Irini, jednak z oceną jej efektów należy jeszcze zaczekać. Z ostrożnym optymizmem natomiast można spoglądać na proces berliński, wyrażający się w obu konferencjach z lat 2020-2021. Udało się bowiem powstrzymać walki, które wybuchły wiosną 2019 r. wraz z ofensywą wojsk Chalify Haftara. Istotną rolę odgrywali tu aktorzy zewnętrzni, którzy - z jednej strony - przyczyniali się do podsycania konfliktu, z drugiej zaś - potrafili zapewne wpłynąć (przede wszystkim Turcja i Rosja, które już w Syrii przetestowały trudną współpracę w warunkach wspierania przeciwnych stron konfliktu) na walczące stro- 
ny, aby zgodziły się na zawieszenie walk i wdrożenie procesu pokojowego. Niełatwo jest przewidzieć jego ostateczne rezultaty, jednak biorąc pod uwagę doświadczenia dekady, jaka minęła od obalenia Kaddafiego, trudno oczekiwać szybkiej stabilizacji Libii po planowanych na grudzień 2021 r. wyborach. Można przyjąć, że sformułowana na początku hipoteza badawcza znajduje swe potwierdzenie. Umiarkowana stabilizacja w Libii stała się rezultatem skumulowanych działań Unii Europejskiej, poszczególnych jej państw, ONZ oraz innych aktorów, takich jak niektóre państwa arabskie, Stany Zjednoczone, Rosja i Turcja. Nie należy jednocześnie ignorować faktu, że wcześniejsze działania części z nich przyczyniały się do eskalacji konfliktu poprzez wspieranie poszczególnych jego stron. Bez wątpienia jednak w najbliższej przyszłości konieczne będzie dalsze zaangażowanie organizacji międzynarodowych, zwłaszcza UE, jak również najważniejszych aktorów państwowych w proces podtrzymywania kruchej stabilności tego państwa, w którym gra interesów różnych podmiotów będzie odgrywała istotną rolę.

\section{Bibliografia}

Berliner Gipfel soll Lage in Libyen stabilisieren, „,Süddeutsche Zeitung”, 14.03.2020.

Berliner Libyen-Konferenz. Schlussfolgerungen der Konferenz, Pressemitteilung 31/2020, 19.01.2020, Presse- und Informationsamt der Bundesregierung, https://www.bundesregierung.de/resource/blob/974430/1713860/ba8f80933b285e37196245cd119fd75b/2020-01-19libyen-konferenz-schlussfolgerungen-data.pdf?download=1.

Decyzja Komitetu Politycznego i Bezpieczeństwa (WPZiB) 2015/1772 z dnia 28 września 2015 r. w sprawie przejścia EUNAVFOR MED do drugiej fazy operacji, określonej w art. 2 ust. 2 lit. b) ppkt (i) decyzji (WPZiB) 2015/778 w sprawie operacji wojskowej Unii Europejskiej $w$ południowym rejonie środkowej części Morza Śródziemnego (EUNAVFOR MED) (EUNAVFOR MED/2/2015), Dziennik Urzędowy Unii Europejskiej, L258, 3.10.2015, s. 5-6.

Decyzja Komitetu Politycznego i Bezpieczeństwa (WPZiB) 2016/118 z dnia 20 stycznia 2016 r. w sprawie wdrożenia przez operację EUNAVFOR MED SOPHIA rezolucji 2240 (2015) Rady Bezpieczeństwa Organizacji Narodów Zjednoczonych (operacja EUNAVFOR MED SOPHIA/1/2016), Dziennik Urzędowy Unii Europejskiej, L23, 29.01.2016, s. 23-24.

Decyzja Rady 2013/233/WPZiB z dnia 22 maja 2013 r. w sprawie misji Unii Europejskiej dotyczacej pomocy $w$ zintegrowanym zarządzaniu granicami w Libii (EUBAM Libya), Dziennik Urzędowy Unii Europejskiej, L138, 24.05.2013, s. 15.

Decyzja Rady (WPZiB) 2015/778 z dnia 18 maja 2015 r. w sprawie operacji wojskowej Unii Europejskiej w południowym rejonie środkowej części Morza Śródziemnego (EUNAVFOR MED), Dziennik Urzędowy Unii Europejskiej, L122, 19.05.2015, s. 31-35.

Decyzja Rady (WPZiB) 2015/778 z dnia 18 maja 2015 r. w sprawie operacji wojskowej Unii Europejskiej w południowym rejonie środkowej części Morza Śródziemnego (EUNAVFOR MED), Dziennik Urzędowy Unii Europejskiej, L157, 23.06.2015, s. 51.

Decyzja Rady (WPZiB) 2016/207 z dnia 15 lutego 2016 r. zmieniająca decyzje Rady 2013/233/ WPZiB w sprawie misji Unii Europejskiej dotyczacej pomocy w zintegrowanym zarzadzaniu granicami w Libii (EUBAM Libya), Dziennik Urzędowy Unii Europejskiej, L 39, s. 45.

Decyzja Rady (WPZiB) 2016/993 z dnia 20 czerwca 2016 r. zmieniająca decyzję (WPZiB) 2015/778 $w$ sprawie operacji wojskowej Unii Europejskiej w południowym rejonie środkowej części Morza Śródziemnego (operacja EUNAVFOR MED SOPHIA), Dziennik Urzędowy Unii Europejskiej, L162, 21.06.2016, s. 18. 
Decyzja Rady (WPZiB) 2017/1385 z dnia 25 lipca 2017 r. zmieniajaca decyzję (WPZiB) 2015/778 w sprawie operacji wojskowej Unii Europejskiej w poludniowym rejonie środkowej części Morza Śródziemnego (operacja EUNAVFOR MED SOPHIA), Dziennik Urzędowy Unii Europejskiej, L194, 26.07.2017, s. 61-62.

Decyzja Rady (WPZiB) 2020/471 z dnia 31 marca 2020 r. uchylająca decyzję (WPZiB) 2015/778 w sprawie operacji wojskowej Unii Europejskiej w poludniowym rejonie środkowej części Morza Śródziemnego (operacja EUNAVFOR MED SOPHIA), Dziennik Urzędowy Unii Europejskiej, L101, 1.04.2020, s. 3.

Decyzja Rady (WPZiB) 2020/472 z dnia 31 marca 2020 r. w sprawie operacji wojskowej Unii Europejskiej na Morzu Śródziemnym (EUNAVFOR MED IRINI), Dziennik Urzędowy Unii Europejskiej, L 101, 1.04.2020, s. 4-10.

Estrada-Canamares M. (2016), Operation Sophia before and after UN Security Council Resolution No 2240 (2015), „European Papers”, vol. 1, no. 1.

EUBAM Libya: Rada przedluża mandat o kolejne dwa lata, komunikat prasowy Rady UE, 18.06.2021, https://www.consilium.europa.eu/pl/press/press-releases/2021/06/18/eubam-libya-councilextends-mandate-for-a-further-two-years/.

General National Congress Elections in Libya. Final Report, July 7, 2012, https://aceproject.org/ ero-en/regions/africa/LY/libya-final-report-general-national-congress-3.

Harchaoui J. (2020), Was folgt aus der Berliner Libyen-Konferenz?, „Vereinte Nationen” 1/2020.

Joint press release of the United Nations, the African Union and the European Union, Abidjan, 29 November 2017, https://ec.europa.eu/commission/presscorner/detail/en/STATEMENT_17_5029.

Kirtzman C. (2020), Sophia to Irini: A Shift in EU Mediterraean Operations, A Path for Europe, 5.11.2020, https://pathforeurope.eu/sophia-to-irini-a-shift-in-eu-mediterranean-operations/.

Kruk A. (2019), Militarne zaangażowanie Niemiec w Afryce - wybrane aspekty, „Rocznik Integracji Europejskiej", nr 13.

Kurz lehnt Neustart für EU-Mission „,Sophia” strikt ab, „Der Standad”, 2.02.2020, https://www. derstandard.at/story/2000114077681/kurzlehnt-neustart-fuer-eu-mission-sophia-strikt-ab.

Libyan Political Agreement, as signed on 17 December 2015, https://menarights.org/sites/default/ files/2016-12/LBY_Political\%20Agreement_ENG_0.pdf.

Maltańska deklaracja członków Rady Europejskiej o zewnętrznych aspektach migracji: kwestia szlaku śródziemnomorskiego, 3 lutego 2017, https://www.consilium.europa.eu/p1/press/press-releases/2017/02/03/malta-declaration/.

Mickiewicz P. (2017), Przeciwdziałanie nielegalnej imigracji droga morska do UE. Źródła i potencjalne formy reakcji, „Krakowskie Studia Międzynarodowe”, nr 1.

Nadzwyczajne posiedzenie Rady Europejskiej (23 kwietnia 2015), komunikat prasowy, https://www. consilium.europa.eu/p1/press/press-releases/2015/04/23/special-euco-statement/.

Resolution 1970 (2011) adopted by the Security Council at its 6491th meeting, on 26 February 2011, https://www.undocs.org/S/RES/1970\%20(2011).

Resolution 1973 (2011) adopted by the Security Council at its a meeting, on 17 March 2011, https:// www.undocs.org/S/RES/1973\%20(2011).

Resolution 2009 (2011) adopted by the Security Council at its 6620th meeting, on 16 September 2011, https://undocs.org/S/RES/2009(2011).

Resolution 2146 (2014) adopted by the Security Council at its 7142nd meeting, on 19 March 2014, https://undocs.org/S/RES/2146(2014).

Resolution 2240 (2015) adopted by the Security Council at its 7531st meeting, on 9 October 2015, https://undocs.org/S/RES/2240(2015). 
Resolution 2509 (2020) adopted by the Security Council at its 8719th meeting, on 11 February 2020, https://undocs.org/en/S/RES/2509(2020).

Resolution 2510 (2020) adopted by the Security Council at its 8722th meeting, on 12 February 2020, https://undocs.org/S/RES/2510\%20(2020).

Szczepankiewicz-Rudzka E. (2018), Libia po interwencji zbrojnej w 2011 roku, „Bezpieczeństwo. Teoria i Praktyka", nr 1.

Schoch B. (2014), Die Libyen-Intervention:Warum Deutschlands Enthaltung falsch war, w: LIbyen: Missbrauch der Responsibility to Protect?, red. G. Beestermöller, Aschendorfff Verlag, Baden-Baden.

von Sponeck H. (2013), Internationale Schutzverantwortung - der lange Weg vom Konzept zur Norm, w: Der Liyen-Krieg. Das Öl und die „,erantwortung zu schützen”, red. J. M. Becker, M. Daxner, G. Sommer, Lit Verlag, Berlin.

Tardy T. (2017), Operation Sophia's world. Changes and challenges, „Brief Issue”, November 2017, European Union Institute for Security Studies.

The Second Berlin Conference on Libya. Conference Conclusions, 23.06.2021, https://www.auswaertiges-amt.de/blob/2467828/97c011e84d3ad46c179c10837058a559/210623-lbyabschlusserk-download-en-data.pdf.

UN: Dauerhafter Waffenstillstand in Libyen vereinbart, „Süddeutsche Zeitung”, 23.10.2020, https:// www.sueddeutsche.de/politik/libyen-waffenruhe-un-1.5091426.

Valetta Summit, 11-12 November 2015. Political declaration, https://www.consilium.europa.eu/media/21841/political_decl_en.pdf.

Valetta Summit, 11-12 November 2015. Action Plan, https://www.consilium.europa.eu/media/21839/ action_plan_en.pdf.

Volk Thomas, Berliner Libyen-Konferenz 2.0. Absichtserklärungen ohne Auswirkungen?, Länderbericht Juni 2021, https://www.kas.de/de/laenderberichte/detail/-/content/berliner-libyen-konferenz-2-0.

Waffenruhe für Libyen, 19.01.2020, https://www.bundesregierung.de/breg-de/suche/libyen-konferenz-in-berlin-1712310.

Widerstand gegen EU-Mission „Sophia” (2020), „Deutsche Welle“, 25.01.2020, https://www. dw.com/de/widerstand-gegen-eu-mission-sophia/a-52145460.

\section{Streszczenie}

Arabska wiosna, która nastąpiła w 2011 r., szczególnie boleśnie doświadczyła Libię, która popadła w otchłań wojny domowej po śmierci wieloletniego dyktatora Muammara Kaddafiego. Chaos, jaki zapanował w Libii spowodował, że upodobniła się ona do państw upadłych i stała się poważnym problemem dla bezpieczeństwa międzynarodowego. Ostatecznie ukształtowały się tam dwa główne ośrodki władzy, popierane przez różnych aktorów stosunków międzynarodowych. Obawa przed terroryzmem oraz niekontrolowanymi migracjami z tego państwa spowodowały, że normalizacja sytuacji w Libii stała się jednym z żywotnych interesów Unii Europejskiej. Celem artykułu jest omówienie kryzysu w Libii w latach 2011-2021 oraz działań Unii Europejskiej na rzecz łagodzenia jego skutków, w tym uruchomienia misji EUBAM Libya, Sophia, czy Irini. Do przygotowania tekstu posłużono się przede wszystkim analizą dokumentów ONZ, UE jak również opracowań na ten temat.

Słowa kluczowe: Libia, Muammar Kaddafi, Fajiz as Saradż, Halifa Haftar, Unia Europejska, Organizacja Narodów Zjednoczonych, UNIMIL, EUBAM Libya, Sophia, Irini 
A decade of crisis in Libya as a challenge for the European Union (2011-2021)

\section{Summary}

The Arab Spring of 2011 hit Libya particularly hard. The state fell into tehe abyss of the civil war following the death of a long-time dictator Muammar Gaddafi. The chaos in Libya made it resemble failed states and turned i tinto a serious problem for international security. Ultimately, two main centres of power were formed there, supported by various actors in international relations. The fear of terrorism and uncontrolled migrations from this country made the normalization of the situation in Libya one of the vital interests of the European Union. The aim of the article is to discuss the 2011-2021 crisis in Libya and the activity of the EU to mitigate its effects, including of the launch of the EUBAM Libya, Sophia and Irini missions. For the preparation of the paper, first of all, the analysis of UN and EU documents and studies on this subject was used.

Key words: Libya, Muammar Gaddafi, Fajez al.-Sarajj, Halifa Haftar, European Union, United Nations, EUBAM Libya, Sophia, Irini 
